This is an original accepted manuscript of an article published by Taylor \& Francis in Middle Eastern Literatures (2015) available online: https://doi.org/10.1080/1475262X.2016.1199097

Accepted version downloaded from SOAS Research Online: http://eprints.soas.ac.uk/33425

Abdel Rahman el-Abnudi (1938 - 21 April 2015)

Yāmnah'1

"Yāmnah" (1997) is 'Abd a-Raḥmān al-Abnūdī's elegy for his aunt, Āmina. It is so popular that the text can be found in a variety of publication venues on line and in print. There are numerous recordings of el-Abnudi performing the poem on youtube as well. The Arabic text on which this translation is based is found in a collection of poems called Al-Aḥzān al-'Ādiyya (Ordinary Sorrows) published in Cairo by Dār Qibā' in 1999. Composed in the southern Egyptian dialect, el-Abnudi's mother tongue, and the main language in which he writes, it recounts the poet's last visit with his favourite aunt in the Upper Egyptian countryside, who called him by his nickname "Romman." It represents for those familiar with the works of the foremost Egyptian colloquial poet el-Abnudi at his best, at once elegiac, humorous, simple and profound.

Good God, Abdelrahman, you have white hair,

How did you get so old, my boy,

and in such a hurry?

When? And how?

Growing old a stranger in foreign lands

is not the same as growing old at home.

Did the women wear you out?

I saw you once on television,

and once someone showed me your picture in the newspaper.

I said to myself Abdelrahman has grown old,

1 Selected by Tamim al-Barghouti. Translated by Wen-chin Ouyang, Tamim alBarghouti and Michael Beard 
I must be long dead by now!

Oh, God, my boy, I worry this life will go on forever,

Sheikh Mahmoud died,

so did Fatmah Ab Gindil.

The vineyard of Ab Ghabban was sold,

and yet I'm still alive,

and it looks like l'll live on and on.

I have lived too long,

Abdelrahman,

long enough to see you grow old.

I heard them say you had children.

So you had children, my boy?

In your old age?

Girls too?

For God's sake, what have you been doing all these years?

Are you waking up only now?

What are you going to do with them?

Anyway--

they're the scent you'll leave behind on this earth.

They will keep each other company.

Or what do you think, Abdelrahman?

We finally caught your scent and had a glimpse of you.

Did it take so long to remember your "Yamnah" and finally to call on her? 
Abdelrahman, my dear boy,

you have my love, by God, and you deserve it,

no matter for how long distance steals you away.

You still have a good heart,

not like those bastards,

who forgot us ages ago!

Is your wife beautiful? How about your children?

Or do they look like us?

What names did you give them? They told me "Ayah" and "Nur".

So, you didn't know how to make a boy?

On a second thought,

the boys we brought to this earth,

did they do us any good in this life?

But men are so easily fooled!

You think Yamnah will live on to wear out still more clothes?

Is that why you brought me cotton and velvet!

You could have given me their money,

I could have bought cream for my knees.

Goodness, Abdelrahman, you're so vain!

I've been here for six years,

nailed to this door, 
No one has come by to say hello, not friends, not strangers.

Leave the velvet and cotton aside.

What use are they to me?

Do I make them into a shroud?

My face has become all wrinkled!

Do you remember Yamnah? Do you remember her face?

Don't ever trust this world.

She is a cheat and a liar!

If death comes for you, my little boy,

Die on spot.

Those she snatched continue to be dear, alive in the heart, as if they'd never been away!

But those who have been dying slowly, piece by piece, dried up while still alive, not even "peace be upon you" comes across their threshold!

As soon as death comes to you, spread your wings, when it calls your name, take off, You will be the winner,

Don't give it a second thought,

Don't think of your son or daughter.

Time lies even when it tells the truth. 
Leave the world to them, completely. Just slip away,

Don't look back!

Inheritance is dust.

The great walls of time are mud.

And your children will survive, with or without you.

\section{O Romman,}

It's quite a long journey,

and whoever makes it even longer, even by one day, is an ass!

The only medicine I want is for the pain in my knee,

not for a longer life,

Don't you ever trust her colours yellow and red!

Wasn't I beautiful once upon a time, my dear boy?

Wasn't I this, wasn't I that,

A tough girl all men feared?

But when did any of you really see me then?

You were only kids!

My girls, Radiyyah and Najiyyah, died and left for good,

and I stayed behind,

What can I do?

Don't you ever live a day longer than your children,

Abdelrahman, don't!

Life is pain and worry in all shapes and colours 
but people don't know it.

And the worst is to live

after your children have died.

You will know then

what death really is!

As soon as it comes to you, jump!

Do you still tell them, up north, those tales of yours,

"Fatnah and Haragi El-Gutt"?

You were a naughty little demon,

contrary,

a loner,

a load of mischief,

hiding in your hypnotic eyes

a hawk,

soaring

as soon as it dives,

all sharp claws and

beak.

But you were never a liar.

l've been here waiting all this time.

Your hair has now turned to white.

The house has grown old too. 
Houses have collapsed before,

but this one hasn't collapsed.

It's waiting faithfully for me to die.

Will you come [to the village] next New Year?

If you do, will you come to my house,

and drink tea with Yamnah?

I will come, my aunt.

And indeed I did.

But Yamnah wasn't there.

Not Yamnah, not the house. 